\title{
Merja Tarvainen
}

\section{Sota- ja jälleenrakennusajan muistelukerronta elämäntarinan säikeenä}

\begin{abstract}
ABSTRAKTI
Artikekeli käsittelee toisen maailmansodan (1939-1945) ja sen jälkeisten vuosien muistelukerrontaa elämäntarinan säikeenä tutkimalla, millaista on sota-ja jälleenrakennusajan muistelukerronta Vammaisena Suomessa 2013-2014 -elämäkertakokoelmassa. Tutkimuksen metodologinen perusta on tarinallisen kiertokulun malli, jonka ytimiä ovat sisäinen ja kerrottu tarina sekä kulttuurinen tarinavaranto. Vammaisten ibmisten ybteys tarinalliseen kiertokulkuun on usein esteellistä, mutta esteisyys rakentuu subteessa kerrottavaan aibeeseen. Sotaaike määrittyi elämäntarinan aineellisena ja kerronnallisena olosubteena, jonka vaikutukset saattoivat ulottua myös myöhempään elämänkulkuun. Jälleenrakennusajan muistelukerronta kiteytyy ristiriitaisten tunteiden kerronnallistumiseen aineellisten kïnnekobtien ja ruumiillisen työn kautta. Raskaita muistoja sanallistettiin esineiden ja paikkojen avulla, jotka välittävät menneisyyden tunnemaailmoja. Yhteys kulttuuriseen tarinavarantoon rakentuu subteessa kerrottuun teemaan ja saavutettavissa oleviin resursseibin, ja yhteys erilaisiin kulttuurisiin tarinaresursseihin vahvistaa kertova toimijuutta ja elämäntarinan rakentamista. Mitä moninaisemmin ibmisellä on mabdollisuus këyttää tarinallisia resursseja elämäntarinansa rakentamiseen, sitä vahvemmaksi hänen narratïvinen toimïuutensa rakentuu. Tämä vahvistaa myös (narratiivista) osallisuutta.
\end{abstract}

Tarinallinen kiertokulku, osallisuus, vammaisuus, sota- ja jälleenrakennusaika

Merja Tarvainen, Yhteiskuntatieteiden laitos, Itä-Suomen yliopisto, merja.tarvainen@uef.fi 


\section{Johdanto}

Me kumpikin muistamme sodan, ei, emme pelkästä̈n muista, me tunnemme sen luissamme ja lihoissamme. Me olemme näbneet pomminkuopat ja palot ja sammutusvesien sä̈bkeen talviyössä. Ja unet, joissa kuljemme kaupungissa, jonka fysionomia on etä̈sesti tuttu; tässä piti olla tori, tuossa se valkea koristeellinen talo, tässä meni ennen kuja talojen lomassa, tuolla oli se korkea aita, kaivo, kivetys jota pitkin bypin pitkissä aamwvarjoissa kohti leipurinliikettä. Sodasta nekin unet kertovat, vaikkea niissä on syvä rauba, sanoi Rose. Ja bän oli sïnä oikeassa, koska tämän tietävät kaikki sodan eläneet: syvin kokemus sodasta on eksyminen tutussa maisemassa, maamerkkien katoaminen, ikiajoiksi. ${ }^{1}$

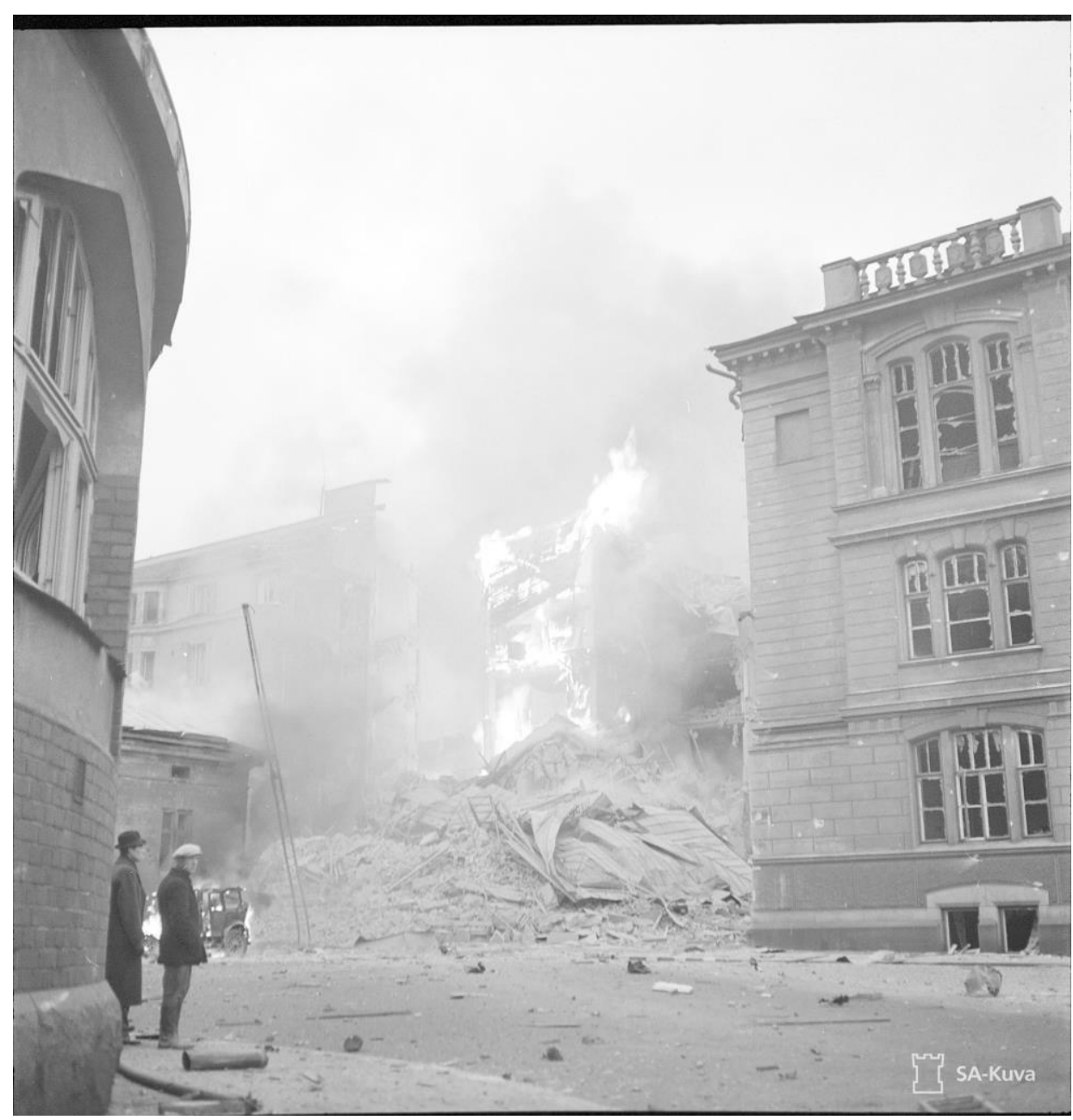

Helsingissä Abrahaminkadun ja Lönnrothinkadun kulmatalo pommituksen jälkeen.

Helsinki 1939.11.30. Lähde: SA-kuva.

Alkusitaatti kiteyttää kirjailija Sirpa Kähkösen sanoin siviilin sotakokemuksen muistoa; se avaa myös muistojen ruumiillisuutta ja aineellisia kiinnekohtia. Kähkönen kuvaa "tutussa maisemassa eksymistä" syvimmäksi kokemukseksi sodasta. Tutussa maisemassa eksytään, kun aineellisen todellisuuden maamerkit ovat kadonneet ikiajoiksi. Katkelmassa kuvataan myös unta, joka voi olla muistelua menneestä 
paikasta, jota ei enää ole, tai tapahtuneesta, joka ei enää palaa. Unessa, kuten muistossakin, voi kulkea etäisesti tutun kaupungin kaduilla ja myös muistaa sen - tai kuten Kähkönen muistuttaa, ei vain muistaa, vaan tuntea luissaan ja lihoissaan sodan, jos on sen elänyt. Sodasta muistuttavat pomminkuopat ja poistuneet maamerkit, jotka olivat ennen niin tutut. Jäljellä ovat vain muistot, joiden sanallistaminen ja sanoiksi taipumisen ehdot kiinnittyvät tarinalliseen kiertokulkuun².

Tässä artikkelissa ${ }^{3}$ käsittelen toisen maailmansodan (1939-1945) ja sen jälkeisten vuosien muistelukerrontaa, joka on tuotettu osana Suomalaisen Kirjallisuuden Seuran ja Kynnys ry:n järjestämää Vammaisena Suomessa 2013-2014 -elämäkertakeruuta. Tutkimuksen metodologinen perusta on tarinallisen kiertokulun malli ${ }^{4}$, ja olen kiinnostunut tarinoiden kiinnittymisestä tai kiinnittymättömyydestä tarinalliseen kiertokulkuun. Tutkimuskysymyksenäni on, millaista sota- ja jälleenrakennusajan muistelukerronta on tässä aineistoissa.

\section{Tarinallinen kiertokulku sekä vammaisten ihmisten elämisen ja kerto- misen ehdot}

Tarinallisuuden ja muistitiedon suhde on ilmeinen ja tutkimuksessa tunnustettu ${ }^{5}$. Tarinallisen kiertokulun ajatus on, että ihminen muodostaa sisäistä tarinaansa itselleen ja kerrottuja tarinoita toisille. Molempia muodostetaan dialogissa kulttuurisen tarinavarannon kanssa, joka tarjoaa resursseja eletyn tulkintaan ja liittää kokemukset osaksi laajempaa tarinallista kiertokulkua. Sisäinen ja kerrottu tarina eivät useinkaan ole yksi-yhteen samoja, vaan kerrottuja tarinoita varioidaan kertomistilanteen ja yleisön mukaan. Lisäksi tarinallisen kiertokulun avainkäsite on kertomisen ja elämisen ehdot, joita rakentavat aineelliset ja kerronnalliset (diskursiiviset) olosuhteet. ${ }^{6}$

Aiempi tutkimus tunnistaa esteitä vammaisten ihmisten mahdollisuuksissa liittyä tarinalliseen kiertokulkuun. Kyse on sekä tarinan kertomisen että vastaanottamisen esteistä; vammaisuusnarratiivin valtavirtaa on ollut tarina yksilöpoikkeavuudesta, ei-toivotusta ruumiillisesta erilaisuudesta. ${ }^{7}$ Etenkin silloin kun oma tarina ei tunnu asettuvan tähän muottiin tai sen haluaisi kerrotuksi toisin, voi eletyn elämän kokemusten jakaminen olla hankalaa, sillä tarinan kertomisen ja vastaanottamisen resurssit ohjaavat toiseuttavaan tulkintaan. Toiseuttava vammaisuustarinamalli vieraannuttaa ihmistä omasta elämäntarinastaan, kun sisäistäkin tarinaa muodostetaan toisten äänellä ja ikään kuin ulkoapäin tulevilla määreillä8. Ihmisen elämäntarinassa voi olla ja usein onkin monta erilaista säiettä, ja tämä vahvistaa myös kertovaa toimijuutta eli ihmisen mahdollisuuksia muodostaa elämäntarinaansa erilaisten tarinamallien avulla ${ }^{9}$.

Kun tarkastellaan vammaisten ihmisten elämäkertoja, on olennaista huomioida yhtäältä vammaisuusnarratiivin rooli ja toisaalta elämätarinan eri säikeet, joihin vammaisuusnarratiivi ei välttämättä liity. Elämäntarinaa on paikallaan tutkia myös muista näkökulmista, jos aineisto suo siihen mahdollisuuden. Tässä artikkelissa kiinnitän huomiota erityisesti muistelukerrontojen ruumiillisuuteen sekä aineellisiin kiinnekohtiin. Ensinnäkin ruumiillisuus viittaa oletukseen, että muisto on niin sanotusti juurtunut ruumii$\operatorname{seen}^{10}$, ja toisekseen on esitetty, että olisi syytä tutkia muistelukerronnassa avautuvia tunteita ja materiaalisuutta ${ }^{11}$. Tunteet ja ruumiillisuus ovat nousseet kiinnostuksen kohteiksi viimeaikaisessa toisen maailmasodan ja sen lähivuosien tutkimuksessa. Esimerkiksi Ville Kivimäen ja Kirsi-Maria Hytösen toimittamassa 
Raubaton rauba. Suomalaiset ja sodan päättyminen 1944-1950 -teoksessa kysytään, "miltä rauha tuntui" ja "avataan ikkuna aikaan, jolloin sota oli vereslihalla". Lisäksi teoksessa muistutetaan myös sodan erilaisista kokemisista sekä painajaisista ja uusista aluista sodan jälkeen. Viime vuosina onkin tutkittu esimerkiksi toisen maailmansodan tunnemuistojen ruumiillisuutta erityisesti sota-ajan aikuisten tai nuorten aikuisten elämässä ${ }^{12}$, mutta myös sota-ajan lapsuuden tutkimuksessa ${ }^{13}$.

Uusin historiantutkimus on ollut kiinnostunut ihmisten kokemusmaailmasta ja tunteista sekä kytkeytymisestä tai kytkeytymättömyydestä kollektiiviseen kertomukseen sodasta. Suomalaisessa tarinavarannossa on tunnistettu kaksi keskeistä tarinalinjaa sotaa seuranneista vuosista. Ensinnäkin on poliittisen kertomuksen tarinalinja, jolloin puhutaan "vaaran vuosista". Toisaalta on suuri selviytymiskertomus, joka kiinnittyy "pula-ajan, työnteon ja eteenpäin pyrkimisen eetokseen". ${ }^{14}$ Kollektiiviset kertomukset ovat yhteisesti jaettua muistamista, tapaa kertoa sekä jaettuja tapoja kertoa tunteista.

\section{Aineisto ja menetelmä}

Tässä tutkimuksessa analysoitava muistelukerronta on muotoutunut osana Suomalaisen Kirjallisuuden Seuran (SKS) ja Kynnys ry:n keräämää "Vammaisena Suomessa 2013-2014" -elämäkertakokoelmaa ${ }^{15}$, mutta vammaisuus ei varsinaisesti tule esiin näissä sota- ja jälleenrakennusajan muistelukerronnoissa. Siihen voi olla monia yksilöllisiä, kerronnallisia ja yhteisöllisiä syitä, kuten vaikkapa se, ettei vammaisuus tuossa elämänvaiheessa liity näiden muistelukertojien elämään. Lisäksi olennaista on huomioida sekin, että vammaisuus-termi muotoutui nykymuotoiseen käyttöönsä 1900-luvun jälkipuoliskolla ja on yhteydessä vammaisliikkeen yhteiskuntapoliittisiin tavoitteisiin. Varhaisempia kokemuksia toki saatetaan kuvata tällä termillä, mutta varsinaisessa aikalaiskäytössä se ei ole ollut ${ }^{16}$. Aineistossa on 1797 sivua tekstiä 37 kirjoittajalta, joista viisi muistelee ja kertoo lapsuuttaan sota-ajan ja lähivuosien Suomessa. SKS kuvaa keruun tyypillisen kirjoittajan olleen "liikuntavammainen nainen, joka oli vammautunut syntymässä tai varhaislapsuudessaan" ${ }^{\prime 17}$. Tässä artikkelissa on mukana sekä miesten että naisten muistelukerrontoja. Aineiston keruusaatteessa kehotettiin aloittamaan "varhaisimmista muistoista" ja kertomaan elämänkulusta "aina nykyhetkeen ja tulevaisuuden pohdintoihin saakka" ja muistutettiin, ettei kaiken kerrotun tarvinnut liittyä vammaisuuden teemaan ${ }^{18}$. Tutkimuksen kannalta nämä ovat olennaisia seikkoja: ensinnäkin on kyse vammaisuuden teemaan kohdentuvasta elämäkertakeruusta, ja toisekseen kaiken kerrotun ei kuitenkaan tarvitse liittyä tähän teemaan. Tämä antaa myös tutkijalle kehotuksen kiinnittää huomiota niihin kerrontoihin, joissa vammaisuuden teemaan ei kiinnitytä.

Tutkimuksen metodologinen perusta, tarinallinen kiertokulku, suuntaa myös luentaa. Sitä voi kuvata muistelukerronnan narratiiviseksi analyysiksi: tutkin, millaista on sota- ja jälleenrakennusajan muistelukerronta tässä aineistoissa eli avaan, mistä asioista näiden sota- ja jälleenrakennusajan muistelukerrontojen ydin rakentuu ${ }^{19}$. Tutkin, mitä ja miten kerrotaan ${ }^{20}$.

Lukiessani aineistoa muita tutkimuksia varten mielenkiintoni kiinnittyi tekstien sota- ja jälleenrakennusajan muistelukerrontoihin. Ne olivat kuin välähdyksiä tai häivähdyksiä menneistä hetkistä, jotka tulivat kerrotuksi elämäntarinan keskellä tai kesken kaiken muun kerronnan. Ryhdyin tutkimaan niitä tarkemmin. Ensin keräsin, tai yritin kerätä, kaikki nämä satunnaiset välähdykset yhteen tiedostoon. Olin useasti epävarma siitä, olinko saanut kerätyksi kaikki, olihan aineisto laaja ja paikoin vaikeasti seurattava. 
Päätin, että luen aineistoa varmuuden vuoksi kahteen eri tapaan: ensinnäkin erikseen näitä sota-ajan muisteluksia etsien, ja toisekseen niin, että pidän huomioni tässä teemassa myös silloin, kun luen aineistoa muihin tutkimuksiin. Rinnakkaislukeminen toikin vielä muutaman rivin lisää, sillä sota-ajan ja sen lähivuosien muistelukerronnat olivat usein upotettuna elämäntarinaan.

Osassa tämän aineiston elämäntarinoita sota-ajan kerrotuista muistoista kerrotaan omana osionaan, esimerkiksi eräs kertoja on otsikoinut "Mitä minulle oli sota"21. Tavanomaisempi kerrontatapa on kuitenkin se, että sota-ajan muistot tulevat kerrotuksi lyhyinä fragmentteina muun elämäntarinan keskelle, ilman kronologista tai paikkaan liittyvää yhteyttä. Tulkitsen tätä siten, että kyse voi olla tietyssä asiayhteydessä heräävästä tunnemuistosta. Elämäntarinan lukijalle näitä yhteyksiä ei välttämättä tekstitasolla juuri avata, joten tämä jää tulkitsevan lukemisen tasolle. Tämä edellytti kulttuurisen tarinavarannon keskeisten kollektiivisten kertomusten tunnistamista. Jaettuja kollektiivisia kertomuksia ovat esimerkiksi edellä kuvattu suuri selviytymiskertomus tai pula-ajan ristiriitainen eetos. Tunnistamisen ohella luin yksilötarinoita sekä suhteessa näihin resursseihin että tarinoina sinänsä. Luentani ytimessä on ruumiillisuus ja materiaalisuus, sillä jaan havainnon siitä, että sota- ja jälleenrakennusajan muistelukerronnan vahvojen tunteiden tutkimuksessa tarvitaan pienten tarinoiden, eletyn ruumiillisuuden ja muiston aineellisten kiinnekohtien tutkimusta $^{22}$. Luen elämisen ja kertomisen ehtoja lähtien siitä, että ruumiillisuus on keskeinen osa kertovaa toimijuutta ja elämisen ehtoja ${ }^{23}$. Kirjoitan seuraavaksi "sota-ajasta elämäntarinan aineellisena ja kerronnallisena olosuhteena", käsittelen "eletyn muistoja ja uusia alkuja sodan jälkeen" sekä "esineitä ja paikkoja muistojen kantajana".

\section{Sota-aika elämäntarinan aineellisena ja kerronnallisena olosuhteena}

Sota-aikaa kerrotaan elämäntarinan olosuhteena ja toisinaan koko elämää suunnanneena kokemuksena. Olosuhteiden kuvaus voi olla tihentynyt hetki, jossa kerronta tiivistyy ja kiertyy tapahtuman ympärille. Tällainen tihentymä saattaa suunnata elämänvaiheen ja -tarinan kerrontaa. Eräs kertoja aloittaa:

Synnyin sodan keskelle, aikaan jolloin kukaan ei tiennyt oliko buomista. ... Syntymä on aina samanlainen tapabtuma, nyt se vain oli jotenkin erilainen. Olihan Suomessa sota. Tykkien jylinä rintamalta kantautui kanas... ${ }^{24}$

Kerronnassa punoutuvat syntymä ja kuolema, toivo ja pelko. "Syntymä on aina samanlainen tapahtuma", kertoja toteaa, mutta jatkaa samaan hengenvetoon "nyt se vain oli jotenkin erilainen". Erilaisuus syntyi sodasta. Kertoja ei tietenkään voi muistaa syntymähetkensä tykkien jylyä rintamalta, mutta tässä keskeisempää onkin se, että "tykkien jylinä rintamalta kantautui kauas". Tätä voi lukea metaforana siitä, miten sota vaikutti silloin siviileihin ja miten muistettu sota vaikuttaa ihmisiin, joilla siihen on ajallista etäisyyttä. "Tykkien jylinä kantautui kauas" on myös ilmaisu, jollaisia on tavattu käyttää sota-ajan muistelukerto- 
muksissa. Pauliina Latvala nimeää tämänkaltaiset ilmaisukäytöt tavaksi "kerronnan jäsentämässä historiassa"25. Tällöin historiaa luodaan, jäsennetään ja ymmärretään tarinoiden avulla. Näissä myös tunteet ja muistot kiinnittyvät osaksi tietämisen tapaa.

Katkelmassa viitataan syntymän ja kuoleman, ja nämä kaksi elämän ääripäätä punoutuvat rinnakkaisina tapahtumina osaksi muistelua ${ }^{26}$. Kertoja jatkaa, että tykkien jylinä "piti ihmiset pelossa sekä varovaisina" ${ }^{27}$. Sota-ajan kerrottu merkitys voi ulottua koko elämäntarinaa suuntaavaksi: "Olen usein ajatellut, että syntymä[aika] elikkä Suomen sota-aika oli määräämässä minkälaisen kohtelun olin myöhemmin saavan. Taistellen on joka asia siitä lähtien tehtävä. Ilman taistelua ei yhtään oikeutta tai etua en ole saanut." ${ }^{28}$ Sota-ajan ankarat elämänolosuhteet luovat kehyksen koko elämäntarinalle, ja sota-ajasta tulee muistettuna koko elämisen ehto.

Sodan kerrottu muisto voi keskittyä myös pieneen ja arkiseen tapahtumiseen. Seuraava kertoja oli sodan aikaan hyvin pieni lapsi. Hän kertoo "ensimmäisen muistikuvansa" olevan sodanaikaisesta väliaikaisesta asuinpaikasta. Hän kuvaa, kuinka "purukasasta löysin keskellä kesää talven. Pihapiirini ulottui johonkin navettarakennusten tienoille. Sieltä jäivät mieleen sahanpurun peittämät, järvestä nostetut jäälohkareet." ${ }^{29}$ Talon ja piharakennusten muodostama pihapiiri on lapselle hänen elämänpiirinsä. Lapsi tutkii uutta, tuntematonta elämänpiiriään ja hämmästyy löytäessään "talven ... keskellä kesää", kun sahanpurukasasta paljastuu jääkimpaleita. Tämä kuvaa sinällään arkista tapahtumaa, joka ei ehkä välttämättä toisena aikana ja toisessa paikassa olisi painunut "ensimmäiseksi muistikuvaksi". Nyt uusi, tuntematon paikka ja olosuhteet sekä myöhemmin eletyn elämän kautta merkityksellistyvä lapsuuden aika ja paikka tekevät tapahtumasta - ja ehkä jo sinällään lapsen mieltä kiehtovasta löydöstä - erityisen muiston. Muistelukerronta saattaa tihetä hetkeksi, joka sävyttää koko elämäntarinaa tai ainakin elämänvaiheesta kertomista. Elämä tulee kerrotuksi tuosta kurkistusaukosta, sen tuntemusten ja edelleen muistettujen ja kerrattujen tuntemusten kautta. Eräässä muistelukerronnassa sota-ajan aineellinen niukkuus ja puute on vaikuttanut myöhempään elämänkulkuun, ja kertoja ajattelee, että elämä olisi mennyt toisin, "jos olisimme saaneet varhaislapsuudessa kaikkea sitä mitä lapset kasvaakseen tarttee" ${ }^{\text {30 }}$.

Sota-ajan muistelut tiivistyvät usein lähdön hetkeen. Tässä kertoja ikävöi armeijaan lähtenyttä veljeään: "... [veli] lähti vapaaehtoisena armeijaan. ... Junamatkalla kuvittelin näkeväni [hänet] aina kun sotilaspuku vilahti jossakin." ${ }^{31}$ Veljen lähtö tiivistyy sotilaspukuisten havainnointiin toiveissa tunnistaa tuttu veli heidän joukostaan. Lähdön hetki on tihentynyttä kokemusta laajemmasta muistosta. Toisaalta juuri lähtöön tiivistyy muistelukerronnan ennakointia siitä, miten tuttu maisema muuttuu iäksii ${ }^{32}$. Sodan vuoksi oli lähdettävä, ja jätettävä tutut paikat, ehkä ikiajoiksi.

\section{Ensimmäisinä vuosinani kun Suomi eli sodan puserruksessa, oli ympärilläni turvalliset läheiset. Jottei minua olisi vähän väliä tarvinnut kiikeuttaa kellaripommisuojaan, eikë muidenkaan perbeenjäsenten jatkuvasti paeta, lähti perheemme [maaseudulle]. ${ }^{33}$}

Tässä kertomuksessa sota "pusertaa", asettaa ahtaat elämisen ehdot. Turvallisuutta elämän ehtojen epävarmuudessa tuovat läheiset ihmiset. Sota-ajan ennakoimattomuus lapsen silmin voi olla esimerkiksi sitä, että "vähän väliä ... kiikutetaan" pommisuojana toimivaan kellariin. "Jatkuvasti paeta", kirjoittaa kertoja, ja tähän tiivistyy jotain jatkuvassa pakovalmiudessa olon ja paon ennakoimattomuuden suhteesta. Kertoja 
muistelee, miten hänen perheensä oli pyrkinyt tuttavaperheen luo, joka ei kuitenkaan voinut ottaa heitä vastaan, koska "talossa oli jo evakoita" eli siirtoväkeä Karjalasta. "Oli lähdettävä ventovieraille ihmisille."34 Kokemus "ventovieraille ihmisille" lähtemisestä on yhteinen monen sotakokemuksen kanssa. Kertoja kuvaa, miten vastaanottaneen talonväen hyväntahtoisuus "helpotti. Kyllä talonväen kanssa tullaan toimeen." ${ }^{35}$

Seuraavan katkelman hetki tihentyy ajallisesti kahtaalle: ensinnäkin siihen, kun kertoja kerrontahetkessä muistelee lapsena kuulemiaan sukutarinoita sekä toisekseen kerrottuun evakkoon lähtöön Karjalasta. Evakkoon lähtö on tihentyvä hetki, joka kerronnassa siroaa aina uusille asuinsijoille asettumiseen ja keskinäiseen apuun. Lähtöhetki kuitenkin tiivistää muiston tunnelman, pelonsekaisen toivon paluusta ja huolen tulevasta. Lähtöhetkeä seuraa matka, josta tässä ei kerrota lainkaan. Sen sijaan siinä korostuu yhdessä pysymisen tahto ja keskinäinen apu.

\begin{abstract}
Samalla kunntelin isoäitini kertomuksia Karjalasta evakkoon lähdöstä: osa lapsista oli kuollut pommituksissa ja osa nälkään. Hän kertoi myös ... enon hyväntabtoisundesta, hän oli ollut aina valmis auttamaan muita. Opin sïnä samalla merkittävän osan Suomen historiaa. Minulle saa kuka tahansa esittää mitä tahansa, mutta isoäidin kertoma on kuitenkin sitä aidointa historiaa. He joutuivat läbtemän evakkoon aivan rajan pinnassa olleesta [koti] kylästä. Kyläläiset päättivät pysyä yhdessä ja palata rauban tultua takaisin, mutta kylä jäi väärälle puolen rajaa, eikä paluuta vanhaan enää ollut. Kylän asuk.kaat asettuivat sodan jälkeen asumaan [samoille seuduille]. He saivat tukea toinen toisistaan. ${ }^{36}$
\end{abstract}

Tämä muistelu kerrotaan elämäntarinan keskellä, ja sen ilmaantuminen kerrontaan (voi) vaikuttaa lukijasta yllättävältä ja aiemmin kerrottuun liittymättömältä. Kertojalle tässä muistossa kuitenkin lienee jotain elämäntarinaa kannattelevaa tai kenties elämänasenteisiin liittyvää. Ainakin tässä katkelmassa on vahva muistitiedon painotus: "samalla kuuntelin ... kertomuksia Karjalasta". Näiden kertomusten myötä "opin siinä samalla merkittävän osan Suomen historiaa". Kertojalle "isoäidin kertoma on kuitenkin sitä aidointa historiaa". Se on osa kertojan suvun tarinaa, lähiyhteisön muistitietoa ja myös kertojan identiteetin rakentumista. Tällöin kyse on kerrotun merkityksestä kertojalle sekä muistitiedon ylisukupolvisuudesta, jossa elettyä kokemusta kerronnallistetaan erilaisten ajallisten etäisyyksien päästä. Kertoja kuvaa myös evakoiden keskinäistä tukea sekä "enon hyväntahtoisuutta" ja auttamishalua. Isoäidin tarinat Karjalasta, evakkoon lähdöstä ja uusille asuinsijoille asettumisesta ovat kerrottua, muistettua ja sukupolvelta toiselle siirrettyä perintöä ${ }^{37}$. Aineellisen perinnön jäädessä Karjalaan tuli aineettomasta perinnöstä entistäkin tärkeämpää:

Tutut karjalaiset tavat ja luottamus Korkeimpaan olivat perheemme arjessa sälyneet, vaikkea lähes kaikeki mun oli ollut pakeko jättää niille sijoilleen. Uutta kotia rakennettiin toivorikkain mielin. Jo seuraavan kevään tullen me pääsimme äidin kanssa kylvämään siemeniä omaan juurikasmaahan. Metsistä me keräsimme sieniä ja marjoja, ja säilöimme niitä. Vuosi vaibtui, ja meillä lapsilla [oli] tebtävät ikëmme mukaan... ${ }^{38}$ 
Tässä kertoja muistelee uuden kodin rakennusta ja arjen rakennusaineita uudessa paikassa. Hän kuvaa myös elämänsä kantavia rakenteita "tutut karjalaiset tavat ja luottamus Korkeimpaan", jotka säilyivät, "vaikka lähes kaikki muu oli ollut pakko jättää niille sijoilleen". Ulla Savolainen kuvaa evakkoon lähtöä Karjalasta siirtymänä kodista kodittomuuteen. Tämänkaltaisessa kerronnassa eri aikatasot, mennyt, nykyisyys ja tuleva, asettuvat erilaisten tunteiden ilmaisualustaksi. ${ }^{39}$ Katkelmassa risteävät toivo ja menetys. "Kaikki muu oli ollut pakko jättää niille sijoilleen" kuvastaa osaltaan sodan syvintä kokemusta: tutun maiseman ja paikan katoamista, ikiajoiksi. Uuden alku muistellaan konkreettisina, ruumiillisina ja materiaalisina tekoina, kuten edellä kerrottuna juurikasmaan rakentamisena, sienestyksenä, marjastuksena ja säilömisenä.

\section{Elettyjä muistoja ja uusia alkuja sodan jälkeen}

Erilaisten tunteiden yhtäaikaista läsnäoloa sodan jälkeisinä vuosina on jäsennetty tunnemaiseman avulla; se kuvaa, kuinka "...oli vain rykelmä monenkirjavia ajatuksia, aavistuksia, toiveita, pelkoja ja mielialoja, joista sekä toistensa vaikutuksesta että täysin irrallisina syntyi laaja tunnetilojen kirjo, jota voisi kutsua tunnemaisemaksi." ${ }^{40}$ Eräs tämän aineiston kertojista muistelee, kuinka "sodan jälkeen oli puutetta kaikesta. ... Työtä oli tehtävä pitkiä päiviä. Suomi piti nostaa jaloilleen. Sotakorvaukset oli maksettava ja raskas sota käyty. Kyllä se vaikutti kaikkien sen kokeneiden mieliin. Minun lapsuus ... oli alkanut sodan aikana ja se [sodan vaikutus elämään] tuntui jatkuvan koko lopun elämän.”41

Kerronnassa sodan jälkeiset elämisen ehtoja eli pula- ja jälleenrakennuksen aikaa kuvataan lapsuusmuistoista kumpuavana, isompana elämään vaikuttavana tuntemuksena. Kertoja kuvaa myös sitä, että sota-ajan "kaiken raakuuden nähtyä"42 monien ihmisten näkemykset elämästä muuttuivat, ja pelko jäi kytemään. Kerronnassa sodan jälkeiset vaaran vuodet ja suuri selviytymiskertomus sekä niiden kautta kerrotut tunteet yhdistyvät kertojan oman elämänhistorian ja sen tunnemuistojen punokseksi. Siinä tuntuu tiivistyvän laajalti yhteistä, jaettua kokemusta elämän ehdoista. Pitkät työpäivät ja Suomen "nostaminen jaloilleen” kiinnitetään oman elämäntarinan kehyksiksi, elämisen ehdoiksi. Tässä kerronnassa sodan aikana alkanut elämäntaival saa sävynsä sodan muistosta ja tuolloin koetusta niukkuudesta. Lisäksi kertoja toteaa, että "kyllä se vaikutti kaikkien sen [sodan] kokeneiden mieliin".

Kertoja jatkaa, että sota-ajan jälkeen koulunkäynnin ja kasvatuksen myötä "meistä kasvoi kovan kurin alla ihmisryhmä, joka itse tienasi itselleen ja lapsilleen leivän, asunnon koulutuksen sekä maksoi työllään sotavelat ja vanhempiensa eläkkeet" ${ }^{43}$. Tämä muistelukerronta vuoropuhelee suuren selviytymiskertomuksen kanssa ${ }^{44}$. Siinä sanoitetaan myös sodanjälkeisen ajan itsekurivaatimusta sekä kovan työnteon merkitystä. Omin käsin tehtyä työtä on kuvattu parantajana ja ilona sodasta selvinneiden ihmisten elämässä. Työn ruumiillisuus (omin käsin) ja materiaalisuus, työstä seuraavat konkreettiset tulokset - kuten vaikka uusi talo - kiinnittivät tekijänsä konkreettisesti muuhun kuin sota-ajan poikkeustilaan. ${ }^{45}$

"Itsevarmuus kasvaa, kun nuorena joutuu tekemään erilaisia työtehtäviä kotona" ${ }^{46}$, kuvailee tämän aineiston kertoja sota-ajan aineellista niukkuutta ja sotaa seuraavien vuosien työtä; kerronnassa ankarien olosuhteiden kautta karaistut toimijat rakentavat parempaa huomista niukoista raaka-aineista. Toimeen 
tarttumisen ja ankaran työnteon ohella kerronnassa nousee pintaan kuitenkin myös toisenlaisia tunnemuistoja: "olihan sota jättänyt isot arvet jokaiseen" ${ }^{47}$. Tässä kerronnassa sodan jättämät isot arvet ja suuri selviytymiskertomus linkittyvät eletyksi muistoksi.

Sota-ajan ja sen jälkeisten vuosien niukkuus ovat useassa kerronnassa olosuhde, johon elämässä koettuja hankaluuksia ja vaikeuksia suhteutetaan. Eräs sota-aikana lapsuuttaan elänyt kertoja vertaa kokemustaan näön menetyksestä sota-ajan kokemuksiin tuumien, että "kun sota-aikana nuoret sokeutuivat, he ovat [nyt] tulleet pitkän taipaleen vailla [näköä]. ... Miksi olisin katkera, [kun] paljon olisi kehnompaa, jos marisisi. Olen koittanut olla sopusoinnussa näköni kanssa..." ${ }^{48}$ Muistelukerronnassa tuntuu olevan sota-ajan tunnemuistoperintönä maanläheistä arkirealismia ${ }^{49}$.

Sota-ajan muistoissa kerrotaan retrospektiivisesti lapsen maailmasta. Seuraavassa odotus ja uuden alku limittyvät:

Lähes koko päivän minä olin istunut portailla ja odottanut, että isoveli tulee, nostaa minut harteilleen ja kirmaa pitkin pibaa kuin varsa, mutta kun bän viimein tuli, oli jo ilta ja minun nukkumaanmenoaika. ... Jatkosodan päättymisestä oli kulunut kolmisen vuotta, veljeä oli hoidettu eri puolilla Suomea sairaaloissa. Hänkin oli ollut sotimassa. Nyt, kun meidän perheemme vihdoin pääsi asettumaan pysyvästi aloilleen, bän tuli auttamaan isää rakennustöissä. Uuden talon valmistumiseen asti oli vielä asuttava evakossa... ${ }^{50}$

Kertomuksessa pieni lapsi odottaa isoveljeään palaavaksi, mutta päivä ehtii jo kääntyä iltaan ennen kuin kauan odotettu veli palaa. Muistelukerrontaan veljen odotuksesta tiivistyy sodanjälkeistä tunnemaisemaa; siinä on läsnä "pelot, toiveet ja helpotuksen tunne" sekä myös "epävarmuus ja tilanteen avoimuus" ${ }^{51}$. Tässä kerronta veljen paluun odotuksesta kytkeytyy myös uuden alkuun ("asettumaan pysyvästi aloilleen”), ja lisäksi veljen paluuseen tiivistyy odotusta, huojennusta ja uuden alun avoimuutta. Kerronnassa uuden talon valmistuminen on merkki mahdollisuudesta asettua asumaan pysyvästi aloilleen. Aiemmassa tunnehistoriallisessa tutkimuksessa uuden talon valmistumiseen sotaa seuranneina vuosina on nähty kiinnittyvän tunnemuistoja oman elämän haltuunotosta sodan traumaattisten kokemusten jälkeen ${ }^{52}$. 


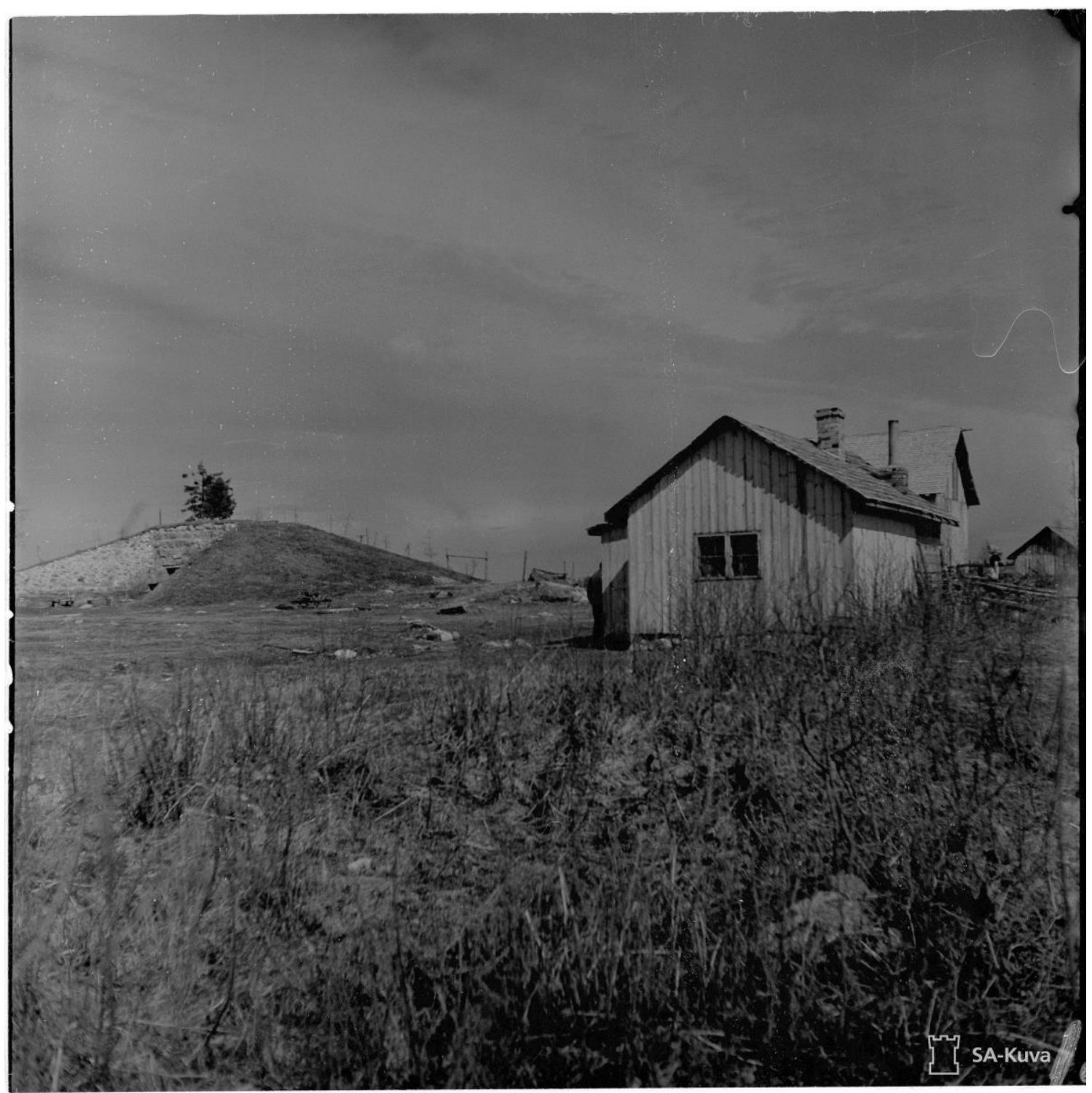

SA-kuva kertoo, että "tämän sievän talon rakensivat talon 18-vnotias poika ja 15-vnotias tytär kahdestaan. Rakennuksen päässä on sauna, jonka valmisti yksi veljeksistä sotaanläbtiessään ja rintamalottana palveleva tytär valmisti kaikeki huonekalut. Jokainen lapsista kantoi oman kortensa kekoon, kotia pystytettäessä. Hotakeka 1943.05.06.

Lähde: SA-kuva.

\section{Esineet ja paikat muistojen kantajana}

Aineiston muistelukerronnoissa raskaiden muistojen sanallistaminen kiinnittyy paikkojen ja esineiden kuvaukseen. Tällainen muisto on syvästi ruumiillinen kokemus, jossa esimerkiksi tutusta paikasta tulee ennakoimattomasti ja peruuttamattomasti tuntematon. Traumaattiset kokemukset kietoutuvat pelkoon. Sota-ajan kerrotuissa muistoissa pelkoon sekoittuu erilaisia tunteita ja muistoja, kuten esimerkiksi pelonsekainen luottamus siitä, että isä palaisi ehjänä rintamalta ${ }^{53}$. Läheisen menettämisen pelkoa kuvataan pommitusten ohella eräänä keskeisimpänä pelon aiheuttajana sota-ajan muistelukerronnoissa ${ }^{54}$. Perhehistorian 
näkökulmasta sota toi särön arkirytmiin, se merkitsi katkosta perheiden tavanomaisessa arkielämään ${ }^{55}$. Tässä aineistoissa kerrottujen muistojen osalta voisi kuvailla, että niissä liikutaan yksilö- ja perhepiirin kokemusten sekä pelon kollektiivisen muistamisen ulottuvuuksilla. Pelkoa kirjoitetaan auki, puetaan sanoiksi. Erään kertojan mukaan ”...sotien jälkeen [pelko] säilyi pitkään kansan mielessä. Voisi sanoa, [että] maaottelu itää vastaan löi leimansa." ${ }^{56}$ Sama kertoja toteaa "lisänä [olleen] joitakin jotka luuloillaan sai aikaan [lisäpelkoa]"57. Hän toteaa, että "kyllä miehiä pelokkaita [oli] samalla lailla varmaankin"58.

Lapsuuden aikainen sodan kokemus tiivistyy hetken tunnemuistoksi. Siinä tihenee erilaisten ja eritasoisten tapahtumahetken tunteiden ja myöhemmin muiston myötä koettujen tunteiden muodostelma. Pelko ja sen muisto liittyvät järkyttävän tapauksen kertautuvaan muistamiseen, tai uneen, jota näkee tahtomattaan yhä uudestaan ja uudestaan. Eräs kertoja muistelee pommin iskeytymistä maahan ja kuinka "pommin tekemä kuoppa oli ... pihalla vuosia". Tapahtunut toistui painajaisena, jossa "juostaan pommi putoaa kuuluu hirvittävä pamaus, tulenloimu rakennuksista". ${ }^{59}$ Edellä kuvatussa katkelmassa tihentyy sodan syvin kokemus, jossa tutun paikan maamerkit muuttavat muotoaan, jotain katoaa ikiajoiksi, ja pomminkuoppa muistuttaa tapahtuneesta. Sotaa seuranneita vuosia ja jopa vuosikymmeniä on kutsuttu rintamamiesten painajaisvuosiksi, joina sodan kokemukset toistuivat unissa. Näitä kokemuksia on viime vuosina tutkittu mentaliteetti- ja yhteisöhistorian kannalta. Unille tyypillistä on ollut karu realismi. ${ }^{60}$ Myös edellä kerrottua sota-ajan lapsisiviilin unikuvausta voi kuvailla karun realistiseksi. Uni kertoo myös avuttomuuden ja hädän tunteista ${ }^{61}$, joista on vaikeaa puhua. Jotkut kokemukset voivat olla ruumiiseen sillä tavoin juurtuneita ja emotionaalisesti tihentyneitä, että niiden kokonaisvaltaista vaikutusta voi olla vaikeaa kääntää sanoiksi ${ }^{62}$.

Toisinaan esineet voivat olla muistin kiinnekohtia ja sanallistamisen apuja; esineet eivät ainoastaan toimi muistikohteina tai muiston kiinnityspaikkoina, vaan tunteiden ja kerronnan kiinnekohtina. Esineet voivat toimia menneen ja nykyhetken tunnemaailman kiinnekohtina. ${ }^{63}$ Joskus esineet ja paikat kiinnittävät tai kiteyttävät muistoja, joista on vaikea puhua tai joita on vaikea saada kerrotuksi. Vaikeneminen, suvun tai yhteisön hiljaisuudet sodasta käyvät esiin eräissä kerronnoissa. Kyse ei ole täydellisen vaikenemisen kulttuurista, vaan vaikeudesta tai haluttomuudesta pukea sanoiksi kipeitä kokemuksia ${ }^{64}$.

Eräs kertojista kuvaa, kuinka "salaisuudet kätkevä puhumattomuus" siirtyi sukupolvesta toiseen: "sodan jälkeen ollessani lapsi, vaiettiin ainakin meidän kodissamme monista asioista. Vaikeneminen oli siirtynyt sukupolvelta toiselle..." ${ }^{95}$. Perheillä tai suvuilla on usein omat muistoista valikoidut kertomuksensa, perinteensä ${ }^{66}$. Kertomusten valikointi tai valikoituminen kytkeytyy tilanteisiin ehtoihin, kuten esimerkiksi siihen, mitä voi tai ajatellaan sopivaksi kertoa. Vaikeneminen on tapa kertoa, mutta se on usein aika kuormittava tapa. Puhumattomuudesta tai pikemminkin huomatusta hiljaisuudesta tai vaillinaisiksi jäävien kertomusten aukkojen tilkitsemisestä voi tulla seuraavan sukupolven tai seuraavien sukupolvien tehtävä. Vaikenemiselle on syynsä, mutta selittämätön sanattomuus jättää kaiherruksen, joskus jopa taakkasiirtymän seuraaville sukupolville ${ }^{67}$. "Kun näitä muistelin, huomasin tahtovani kirjoittaa tästä ja näin päästää pienen tytön syyllisyydestä’" ${ }^{68}$. Kertoja etsii ja lukee sukunsa tarinaa esineistä, jotka muistuttavat menneestä. Esineet kantavat menneisyyttä: "Vain tavarat viittasivat sotaan. Muistini ei ulottunut sinne asti." ${ }^{69}$ Sota tulee muistetuksi ja kerrotuksi esineiden kautta:

Kun menin kammarin jykevän ja vääräsäärisen pöydän alle, pystyin lukemaan pobjalevystä [nimen]. Nyt pöytä oli meidän. Muissakin kalusteissa oli nimiä. Jos ne pubuisivat, osaisivat ne kertoa enemmän 
sodasta kuin minä lukemaan oppinut pikekutyttö. Kalusteet oli joksikin aikaa pitänyt bylätä, pienimmät esineet olivat olleetpeitossa mullan alla. Nappilaatikosta löytyi kokardeja ... sodanaikaisista kenttäharmaista. ${ }^{70}$

Perheet ja suvut tekevät tarinaansa valikoiden: tapahtunutta ja siihen liittyviä tunteita tulkitaan sekä elämänkokemuksen että yleisempien kerronnan ehtojen suhteen. Ruth Finnegan muistuttaa siitä, etteivät yksittäiset kertojat aina suinkaan ole täysin tietoisia siitä, miten he tähän perintöön liittyvät ja kuinka se vaikuttaa heihin ja heidän elämäntarinaansa. Lisäksi tämänkaltainen aineeton perintö voi vaikuttaa ulkopuoliselle kuulijalle tai lukijalle irrallisilta lausahduksilta tai pieniltä tarinoilta. ${ }^{71}$ Tutkija-lukijana tulkiten nappilaatikko-tarinaan tiivistyy esineisiin kytkeytyvää muistitietoa ja tunnemuistoja, joiden kertaamiseen ja uudelleen tulkintaan esineet voivat toimia kanavana.

Kertomuksessa pieni, juuri lukemaan oppinut tyttö ryömii kammarin pöydän alle ja tavailee pöydän pohjalevyä. Pohjalevyssä olevista kirjaimista hahmottuu tuttu nimi. Pöytä on siirtynyt tytön perheelle, ja siihen sisältyy menetyksen ja uuden ristiriitainen tunne. Tyttö tuumiikin, että "jos ne [esineet] puhuisivat, osaisivat ne kertoa enemmän sodasta kuin minä”. Mutta esineet vaikenevat ja kertovat tarinaansa vain, jos osaa kysyä oikeat kysymykset ja saa ne puhumaan. Kun kertomuksen päähenkilö, pieni tyttö, tutkii tuttuja esineitä, kerii kertoja esiin menneisyyden tunnemaisemaa: esineiden hylkäämistä ja niiden kätkemistä sekä uudelleen löytämistä. Kerronta päättyy nappilaatikosta löytyviin kokardeihin.

Sota-ajan ja sitä seuranneiden lähivuosien muistot voivat olla kuin nappilaatikosta löytyvät irralliset, paikoiltaan tipahtaneet tai irrotetut kokardit, jotka etsivät paikkaansa tullakseen ymmärretyksi ihmisen elämänhistoriassa. Kokardi merkitsee asun esimerkiksi sotilaspuvuksi. Sota-ajan muistot voivat tuntua kokardeilta nappilaatikossa: toisaalta ne kuuluvat kokoelmaan, mutta toisaalta ne usein kuitenkin vaativat läsnäolollaan erityistä huomiota muihin muistoihin nähden. Ne tuntuvat muistoilta, jotka tökkäävät esiin arkisessa tilanteessa silloinkin, kun sitä vähiten odottaisi. Ja kuitenkin jollekin toiselle nappilaatikon tutkijalle kyseessä voi olla vain kokoelma nappeja, ja ehkä kokarditkin jäävät huomiotta muiden esineiden joukkoon.

\section{Sota- ja jälleenrakennusajan muistelukerronta ja tarinallinen kierto- kulku}

Tässä artikkelissa tutkin, millaista on sota- ja jälleenrakennusajan muistelukerronta Vammaisena Suomessa -aineistossa. Sota-ajan muistot tulivat kerrotuiksi tyypillisesti tihennettyinä hetkinä eli yksittäisen hetken tai yksittäisten hetkien kautta. Tihennetyt hetket kertovat lähdöistä ja ääriolosuhteista, ja niihin tiivistyy tunteita. Kuten Ulla Savolaisen tutkimassa evakkolapsuuden muistelukerronta-aineistossa, myös tässä aineistossa "lentokoneet, pommitukset ja perheenjäsenten menettäminen" kerrottiin sota-ajan keskeisinä pelon aiheuttajina. Sota-aika ja sitä seuranneet lähivuodet elämän olosuhteena asettavat sen eläneet ja kokeneet suhteuttamaan elämäänsä siihen. ${ }^{72}$ Kansallinen ja yksityinen muisto kietoutuivat elämäntarinan säikeen syiden ja seurausten tulkinnan logiikassa. 
Jälleenrakennusvuosien eletyt ja kerrotut muistot olivat tuntuvasti materiaalisia ja tunnemuistot liittyvät aineellisiin kiinnekohtiin. Nämä muodostivat vastakohtapareja: toisaalta oli pula-aika, toisaalta uusi talo merkkinä uuden alusta. Kerrotut muistot kytkeytyvät konkreettisiin paikkoihin ja esineisiin. Muistelukerronta avasi kokemuksia aineellisesta niukkuudesta ja suoranaisesta puutteesta, ja jälleenrakennuksen muistot kuvasivat konkreettista työtä ja sen merkityksiä yksilöllisesti, yhteisöllisesti ja yhteiskunnallisesti. Jälleenrakennus kiinnitti työn konkreettisen tekemisen sekä tuloksista seuraavan palkitsevuuden tunteen myötä rauhan ajan arkeen.

Myös tämän aineiston valossa esineet ja paikat voivat toimia muistitiedon sekä vaikeasti kerronnallistuvien muistojen ja tunteiden kiinnekohtina ${ }^{73}$. Tällöin esineet yhdistävät kertojan tunnemaailmaan, jota hän kerran eli ja koki sekä mahdollistavat sen uudelleen arvioinnin kerrontahetkessä. Lisäksi paikkoihin kiinnittyvä emotionaalisesti tihentynyt tunnemuisto liittyy sota-ajan muistelukerronnassa "eksymiseen tutussa maisemassa", jota kirjailija Sirpa Kähkönen kuvaa sodan syvimpänä kokemuksena. Kyse on myös siitä, kuinka kertojat pyrkivät välittämään sitä tunnemaailmaa, jota he kerran elivät sekä tekemään sitä ymmärrettäväksi nykykuulijoille ${ }^{74}$. Ville Kivimäen mukaan "vaikenemista ja raadantaa suomalaisena sodanjälkeisenä mentaliteettina on toisteltu kliseeksi asti, mutta kyse ei ole pelkästä katteettomasta stereotypiasta". Tämänkin aineiston kertojat toivat esille muun muassa sitä, mitä aiempi tutkimus on kuvannut "henkilökohtaisten vastoinkäymisten ja epävarmuuden työntämis[en]ä syrjään sitkeän puurtamisen ja hiljaisen kuuliaisuuden" avulla. Suuren selviytymiskertomuksen ytimessä ovat"työ, itsehillintä ja omien pyyteiden syrjään työntäminen", joita on kuvattu myös sodan ja rauhan avainkokemuksen käsitteellä. ${ }^{75}$

Kirjoitetun elämäntarinan muotoilu voi nostaa pintaan sellaisia tunnemuistoja, joita on voinut olla hankala käsitellä tai sanallistaa, mutta jotka kuitenkin ovat vaikuttaneet elämään. Tunnemuistoissa yksityinen, eletty tarina kohtaa yhteisessä tarinavarannossa olevien resurssien mahdollisuudet ja rajat: Mitä voin kertoa, miten voin kertoa ja tulla ymmärretyksi? Niinpä ajattelenkin, että elämän auki keriminen ja sanoittaminen toisille luettavaksi on voinut vaikuttaa myös siihen, miten ja miksi sota-aikaa on muisteltu ja kerrottu. Sota- ja jälleenrakennusaika tulee kerrotuksi elettynä ja muisteltuna olosuhteena, jota tulkitaan myös vasten elettyä elämänpolkua. Oman kokonaisuutensa muodostavat esineisiin ja paikkoihin kätketyt sanat: "jos ne puhuisivat, osaisivat ne kertoa enemmän sodasta kuin minä"76, kuten eräs kertoja toteaa. Esineet eivät ole pelkästään muistin kohteita, vaan myös (menneiden) tunnemaailmojen kiinnekohtia ${ }^{77}$.

Kirjoituskeruussa muotoutuneiden aineistojen tutkimuksen kannalta keskeinen kysymys on, kenenä vastaajat kirjoittavat ${ }^{78}$. Tämän aineiston kerrontaehdot rakentuivat jokaiselle kertojalle yhteisestä kirjoituskutsusta, jossa kutsuttiin kertomaan elämästä vammaisena Suomessa. Lisäksi jokaisella kertojalla oli omat yksilöllisen elämänkulkunsa ehdot ja puitteet, joissa hän tarinaansa kertoi. Keskeinen lähdekriittinen ja myös tutkimuseettinen seikka liittyy siihen, että kyse on retrospektiivisestä lapsuuskerronnasta, jota tehdään eletyn elämän kokemuksen ja kerrontahetken orientaatioiden ehdoissa. Lapsen elämänolosuhteet ovat aina annetut, vasta vanhemmalla iällä ihminen saattaa kriittisesti pohtia lapsuutensa elinoloja ja ehtoja. Tällä aineistolla ei myöskään tavoiteta kokemusta varsinaisesti vammaisuudesta ja lapsuudesta sota- ja jälleenrakennusajalta.

Menneisyyden tunnemaailmojen kerronnalla on yhteys kuulumisen politiikkaan nykyhetken yhteiskunnassa $^{79}$. Vammaistutkimuksen näkökulmasta tämä on jatkohuomiota vaativa asia: osallisuus (inclusion) on nykypäivän vammaispolitiikan ydintavoite, sillä vammaisuudella on pitkä menneisyys marginaalisoinnin ja ulossulun (exclusion) suhteen ${ }^{80}$. Elämä punoutuu tarinaksi useiden kulttuuristen resurssien 
avulla. Esimerkiksi vammaisuuden tarinamallit ovat jännitteisiä, ja ihminen joutuu puntaroimaan niiden roolia suhteessa elettyyn elämäänsä ja kerrottuun tarinaansa. Tässä tarkastellut sota- ja jälleenrakennusajan muistelukerronnat ovat tunnemuistona latautuneita ja usein vaikeasti sanallistuvia kokemuksia, joita kuitenkin laajalti tunnistetaan tarinallisessa kiertokulussa. Yhteys kulttuuriseen tarinavarantoon rakentuu suhteessa kerrottuun teemaan ja saavutettavissa oleviin resursseihin. Ihmisen elämäntarina suhteessa kulttuuriseen tarinavarantoon punotaan erilaisista säikeistä, joiden kertomista rytmittävät erilaiset ehdot. Tältä kannalta katsottuna nämä elämäntarinan säikeet ilmentävät vahvaa kertovaa toimijuutta sekä osallisuutta vuoropuheluun laajalti jaettujen yhteisten kulttuuristen resurssien kanssa.

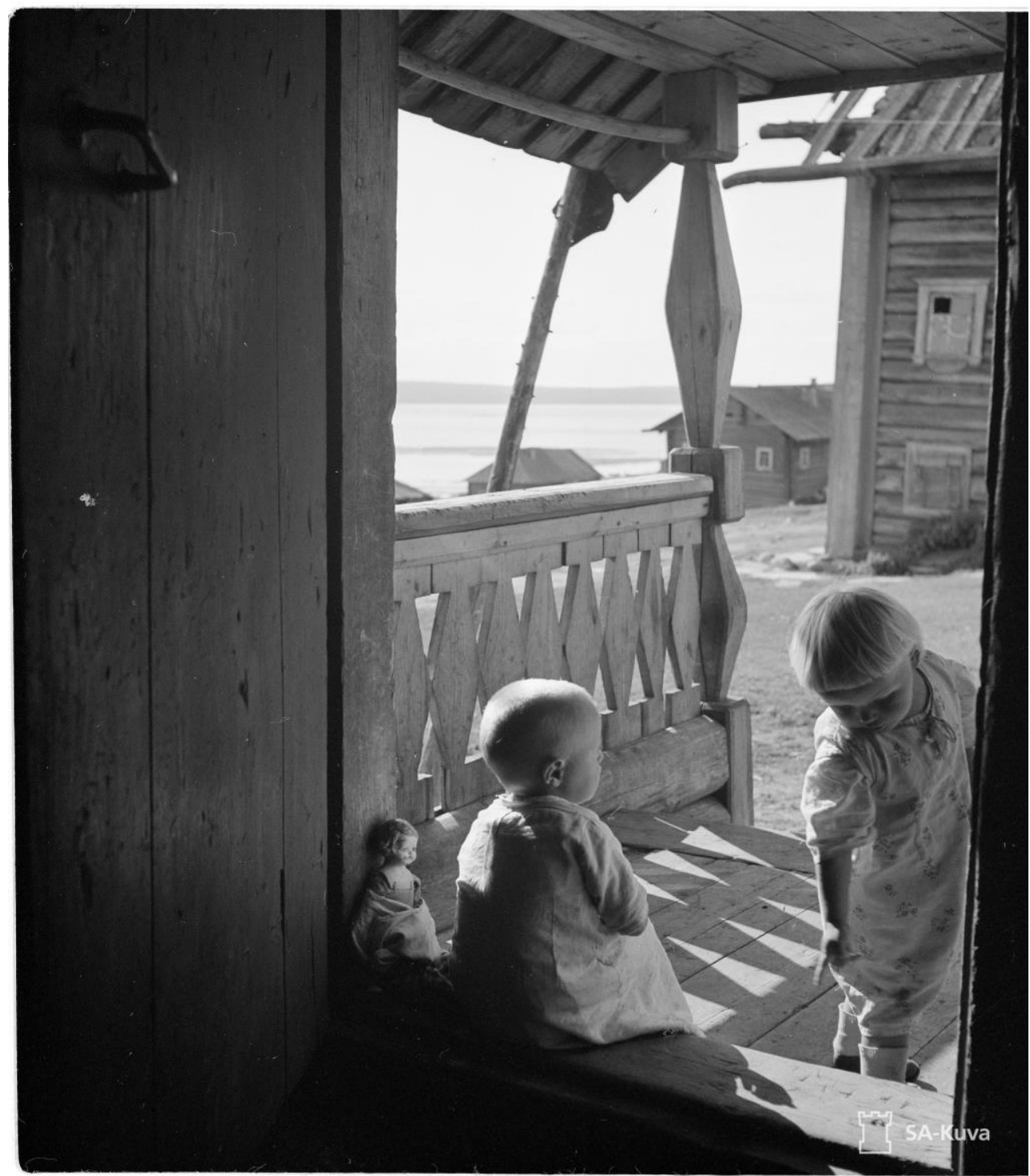

Pieniä lapsia leikeissään. 1942.07.28. Lähde: SA-kuva. 


\section{Lähdeluettelo}

\section{Arkistolähteet}

Vammaisena Suomessa 2013-2014. Suomalaisen Kirjallisuuden Seuran Kansanrunousarkisto (SKS KRA).

\section{Kaunokirjallisuus}

Kähkönen, Sirpa. Tankkien kesä. Helsinki: Otava, 2016.

\section{Kuvat}

SA-kuva-arkisto. http://sa-kuva.fi/neo?tem=webneofin

\section{Sähköiset lähteet}

SKS. Vammaisena Suomessa -elämäkertakeruun saate. SKS KRA ja Kynnys ry, 2013. http://neba.finlit.fi/kra/keruut/vammaisuus.pdf (Luettu 17.5.2017)

SKS. Omaelämäkerroilla parannetaan vammaisten asemaa. 2014. https://www.finlit.fi/fi/ajankohtaista/uutiset/omaelamakerroilla-parannetaan-vammaisten-asemaa\#.XOPPQ6RS9aQ (Luettu 21.5.2017)

\section{Tutkimuskirjallisuus}

Baldwin, Clive. Narrative Social Work. Theory and Application. Bristol: Policy Press, 2013. https://doi.org/10.2307/j.ctt1t89hwd

Campbell, Fiona Kumari. Contours of Ableism: The Production of Disability and Abledness. Basingstoke: Palgrave Macmillan, 2009. https://doi.org/10.1057/9780230245181

De Nardi, Sarah. “An embodied approach to Second World War storytelling mementoes. Probing beyond the archival into the corporeality of memories of the resistance." Journal of Material Culture 19, no. 4 (2014): 443-464. https://doi.org/10.1177/1359183514554987

Finnegan, Ruth. "Family myths, memories and interviewing." Teoksessa The Oral History Reader, toimittanut Robert Perks ja Alistair Thomson, 177-183. Toinen painos. London: Routledge, 2006. 
Harjula, Minna. "Hyvät, pahat ja kelvolliset. Vammaisuus suomalaisessa yhteiskunnassa 1800-luvun lopulta 1930-luvun lopulle." Teoksessa Kuokkavieraiden pidot. Historian marginaalista marginaalihistoriaan, toimittanut Jarmo Peltola ja Pirjo Markkola, 107-121. Tampere: Vastapaino, 1996.

Hynninen, Anna. "Arkistokirjoittamisen kontekstualisointi." Teoksessa Tekstien rajoilla. Monitieteisiä näkëkulmia kirjoitettuibin aineistoibin, toimittanut Sami Lakomäki, Pauliina Latvala, ja Kirsi Laurén, 259-295. Helsinki: SKS, 2011.

Hytönen, Kirsi-Maria. "Ei elämääni lomia mabtunut": naisten muistelukerrontaa palkkatyöstä talvi-ja jatkosotien ja jälleenrakennuksen aikeana. Joensuu: Suomen kansatietouden tutkijain seura, 2014.

Hänninen, Vilma. Sisäinen tarina, elämä ja muutos. Tampere: Tampereen yliopisto, 1999.

Kirves, Jenni. "Elämä omiin käsiin. Traumoista selviytymiseen." Teoksessa Raubaton rauba. Suomalaiset ja sodan päättyminen 1944-1950, toimittanut Ville Kivimäki ja Kirsi-Maria Hytönen, 257-281. Toinen painos. Tampere: Vastapaino, 2016.

Kivimäki, Ville. "Between Defeat and Victory: Finnish Memory Culture of the Second World War." Scandinavian Journal of History 34, no. 4 (2012): 482-504.

https://doi.org/10.1080/03468755.2012.680178

Kivimäki, Ville. "Hämärä horisontti, avautuvat tulevaisuudet. Suomalaissotilaat ja syksyn 1944 tunnemaisema." Teoksessa Raubaton rauba. Suomalaiset ja sodan päättyminen 1944-1950, toimittanut Ville Kivimäki ja Kirsi-Maria Hytönen, 72-100. Toinen painos. Tampere: Vastapaino, 2016a.

Kivimäki, Ville. "Uusi Suomi. Sotasukupolvi ja sodanjälkeinen aika." Teoksessa Raubaton rauba. Suomalaiset ja sodan päättyminen 1944-1950, toimittanut Ville Kivimäki ja Kirsi-Maria Hytönen, 285-321. Toinen painos. Tampere: Vastapaino, 2016b.

Kivimäki, Ville, Kirsi-Maria Hytönen ja Petri Karonen. "Ennen huomispäivää. Toisen maailmansodan päättyminen Suomessa ja Euroopassa." Teoksessa Raubaton rauba. Suomalaisetja sodan päättyminen 19441950, toimittanut Ville Kivimäki ja Kirsi-Maria Hytönen, 11-36. Toinen painos. Tampere: Vastapaino, Tampere 2016.

Kivirauma, Joel. "Johdanto." Teoksessa V ammaisten elämä \& elämäkerta. Tulkintoja vammaisundesta 1900luvun Suomessa, toimittanut Joel Kivirauma, 6-16. Helsinki: Kynnys ry, 2015.

Korjonen-Kuusipuro, Kristiina ja Anna-Kaisa Kuusisto-Arponen. 'Muistelun monet muodot. Kertomus, kehollisuus ja hiljaisuus paikan tietämisen tapoina." Elore 24, no. 1 (2017).

https://doi.org/10.30666/elore. 79278

Koskinen-Koivisto, Eerika. A Greasy-Skinned Worker-Gender, Class and Work in the 20 th-Century Life Story of a Female Labourer. Jyväskylä: Jyväskylän yliopisto, 2013.

Koskinen-Koivisto, Eerika ja Oula Seitsonen. “Landscapes of Loss and Destruction: Sámi Elders’ Childhood Memories of the Second World War.” Ethnologia Europaea 49, no. 1 (2019): 24-40.

https://doi.org/10.16995/ee.816 
Kuusisto-Arponen, Anna-Kaisa \& Ulla Savolainen. "The Interplay between Memory and Matter: Narratives of Former Finnish Karelian Child Evacuees." Oral History 44, no.2 (2016): 59-68.

https://www.jstor.org/stable/24892983

Latvala, Pauliina. "Mikä määrittää suvun muistitiedosta kertomista?” Elore 2 (2000).

http://www.elore.fi/arkisto/2 00/lat200.html https://doi.org/10.30666/elore.78289

Meinander, Henrik. Suomi 1944. Sota, ybteiskunta, tunnemaisema. Helsinki: Siltala, 2009.

Nevala, Seija-Leena ja Kirsi-Maria Hytönen. "Toimet, työt ja taakat." Teoksessa Raubaton rauba. Suomalaiset ja sodan päättyminen 1944-1950, toimittanut Ville Kivimäki ja Kirsi-Maria Hytönen, 151-172. Toinen painos. Tampere: Vastapaino, 2016.

Peltonen, Matti. Mikrohistoriasta. Helsinki: Gaudeamus, 1999.

Polkinghorne, Donald E. 1995. "Narrative Configuration in Qualitative Analysis." Teoksessa Life History and Narrative, toimittanut Richard Wisniewski ja J. Amos Hatch, 5-23. London; Washington, DC:

Falmer Press.

Portelli, Alessandro. "Mikä tekee muistitietotutkimuksesta erityisen?" Teoksessa Muistitietotutkimus. Metodologisia kysymyksiä, toimittanut Outi Fingerroos, Riina Haanpää, Anne Heimo, ja Ulla-Maija Peltonen, 49-64. Tietolipas 214. Helsinki: SKS, 2006.

Savolainen, Ulla. Muisteltu ja kirjoitettu evakkomatka. Tutkimus evakekolapsunden muistelukerronnan poetiikasta.

Kultaneito XV. Joensuu: Suomen Kansantietouden Tutkijain Seura, 2015.

https://doi.org/10.30666/elore.79190

Siltala, Pirkko. Taakkasiirtymä. Trauman siirto yli sukupolvien. Helsinki: Therapeia-säätiö, 2016.

Smith, Brett ja Andrew C. Sparkes. "Narrative and its potential contribution to disability studies." Disability \& Society 23, no. 1 (2007): 17-28. https://doi.org/10.1080/09687590701725542

Tarvainen, Merja. “Ableism and the Life Stories of People with Disabilities." Scandinavian Journal of Disability Research 21, no. 1 (2019): 291-299. http://doi.org/10.16993/sjdr.632 
${ }^{1}$ Sirpa Kähkönen, Tankkien kesä (Helsinki: Otava, 2016), 10.

${ }^{2}$ Vilma Hänninen, Sisäinen tarina, elämä ja muntos (Tampere: Tampereen yliopisto, 1999).

3 Artikkeli muotoutui Suomen Akatemian rahoittamassa Ruumiillisen erilaisuuden tarinat -tutkimushankkeessa (päätösnro: 299172).

${ }^{4}$ Hänninen, Sisänen tarina, elämä ja muutos.

${ }^{5}$ Esim. Alessandro Portelli, "Mikä tekee muistitietotutkimuksesta erityisen?”, teoksessa Muistitietotutkimus. Metodologisia kysymyksiä, toim. Outi Fingerroos, Riina Haanpää, Anne Heimo, ja Ulla-Maija Peltonen (Helsinki: SKS, 2006), 49-64.

${ }^{6}$ Hänninen Sisäinen tarina, elämä ja muntos, 21-23. Muistitietotutkimuksessa menetelmää ovat edistäneet esim. Eerika Koskinen-Koivisto 2013 ja Kirsi-Maria Hytönen 2014.

${ }^{7}$ Fiona Kumari Campbell, Contours of Ableism: The Production of Disability and Abledness (Basingstoke: Palgrave Macmillan, 2009); Merja Tarvainen, “Ableism and the Life Stories of People with Disabilities." Scandinavian Journal of Disability Research 21, no. 1 (2019), 291-299.

${ }^{8}$ Campbell, Contours of Ableism: The Production of Disability and Abledness, 16-29.

${ }^{9}$ Clive Baldwin, Narrative social work. Theory and application (Bristol: Policy Press, 2013), 43, passim.

${ }^{10}$ Sarah De Nardi, "An embodied approach to Second World War storytelling mementoes. Probing beyond the archival into the corporeality of memories of the resistance." Journal of Material Culture 19, no. 4 (2014), 443-464.

${ }^{11}$ Sarah De Nardin ohella myös esim. Anna-Kaisa Kuusisto-Arponen ja Ulla Savolainen, "The Interplay between Memory and Matter: Narratives of Former Finnish Karelian Child Evacuees.” Oral History 44, no. 2 (2016): 59-68.

${ }^{12}$ Esim. Sarah De Nardi, "An embodied approach to Second World War storytelling mementoes. Probing beyond the archival into the corporeality of memories of the resistance." Journal of Material Culture 19, no. 4 (2014): 443-464; Kirsi-Maria Hytönen, "Ei elämääni lomia mabtunut": naisten muistelukerrontaa palkekatyöstä talvi-ja jatkosotien ja jälleenrakennuksen aikana.

${ }^{13}$ Esim. Ulla Savolainen, Muisteltu ja kirjoitettu evakkomatka. Tutkimus evakekolapsunden muistelukerronnan poetiikasta. (Joensuu: Suomen Kansantietouden Tutkijain Seura, 2015); Eerika Koskinen-Koivisto ja Oula Seitsonen, "Landscapes of Loss and Destruction: Sámi Elders' Childhood Memories of the Second World War.” Ethnologia Europaea 49, no. 1 (2019), $24-40$.

${ }^{14}$ Ville Kivimäki, Kirsi-Maria Hytönen ja Petri Karonen, "Ennen huomispäivää. Toisen maailmansodan päättyminen Suomessa ja Euroopassa." Teoksessa Raubaton rauba. Suomalaiset ja sodan päättyminen 1944-1950, toim. Ville Kivimäki ja KirsiMaria Hytönen (Tampere: Vastapaino, 2016), 28-33; Ville Kivimäki, "Between Defeat and Victory: Finnish Memory Culture of the Second World War." Scandinavian Journal of History 34, no. 4 (2012), 482-504.

15 SKS, V ammaisena Suomessa -elämäkertakeruun saate 2013. Kynnys ry on valtakunnallinen vammaisorganisaatio, joka edistää vammaisten ihmisten ihmisoikeuksia. Aineistoa säilyttää SKS KRA, josta se on saatavilla tutkimuskäyttöön. Pieni osa aineistoa on saatavilla myös Yhteiskuntatieteellisen tietoarkiston kautta, ks. aineisto-opas: https://services.fsd.uta.fi/catalogue/FSD3040/PIP/dgF3040.pdf. Keruuhanketta rahoitti Suomen Kulttuurirahasto.

${ }^{16}$ Joel Kivirauma, "Johdanto." Teoksessa Vammaisten elämä \& elämäkerta. Tulkintoja vammaisundesta 1900-luvun Suomessa, toim. Joel Kivirauma (Helsinki: Kynnys, 2015), 6-16; ks. myös Minna Harjula "Hyvät, pahat ja kelvolliset. Vammaisuus suomalaisessa yhteiskunnassa 1800-luvun lopulta 1930-luvun lopulle." Teoksessa Kuokkavieraiden pidot. Historian marginaalista marginaalibistoriaan, toim. Jarmo Peltola ja Pirjo Markkola (Tampere: Vastapaino, 1996), 107-121.

${ }^{17}$ SKS, Omaelämäkerroilla parannetaan vammaisten asemaa 2014.

18 SKS, Vammaisena Suomessa -elämäkertakeruun saate.

${ }^{19}$ Donald E. Polkinghorne, "Narrative Configuration in Qualitative Analysis." Teoksessa Life History and Narrative, toim. Richard Wisniewski ja J. Amos Hatch (London; Washington, DC: Falmer Press, 1995), 5-23.

${ }^{20}$ Brett Smith ja Andrew C. Sparkes, "Narrative and its potential contribution to disability studies." Disability \& Society 23, no. 1 (2007): 20.

${ }^{21}$ Vammaisena Suomessa 2013-2014 (jatkossa VS), 248. Suomalaisen Kirjallisuuden Seuran Kansanrunousarkisto (SKS KRA).

${ }^{22}$ Esim. Eerika Koskinen-Koivisto ja Oula Seitsonen, “Landscapes of Loss and Destruction: Sámi Elders' Childhood Memories of the Second World War." Ethnologia Europaea 49, no. 1 (2019): 24-40; Sarah De Nardi, “An embodied approach to Second World War storytelling mementoes. Probing beyond the archival into the corporeality of memories of the resistance." Journal of Material Culture 19, no. 4 (2014): 443-464; Anna-Kaisa Kuusisto-Arponen ja Ulla Savolainen, "The Interplay between Memory and Matter: Narratives of Former Finnish Karelian Child Evacuees." Oral History 44, no. 2 (2016): 59-68.

${ }^{23}$ Donald E. Polkinghorne, "Narrative Configuration in Qualitative Analysis." Teoksessa Life History and Narrative, toim. Richard Wisniewski ja J. Amos Hatch (London; Washington, DC: Falmer Press, 1995), 17; Brett Smith ja Andrew C. Sparkes, "Narrative and its potential contribution to disability studies." Disability \& Society 23, no. 1 (2007): 17-28. ${ }^{24}$ VS 620, 638. SKS KRA.

${ }^{25}$ Pauliina Latvala,"Mikä määrittää suvun muistitiedosta kertomista?” Elore 2 (2000).

${ }^{26}$ Ks. myös Sarah De Nardi, “An embodied approach to Second World War storytelling mementoes. Probing beyond the archival into the corporeality of memories of the resistance." Journal of Material Culture 19, no. 4 (2014): 443-464.

27 VS 620. SKS KRA.

${ }^{28}$ VS 620. SKS KRA.

${ }^{29}$ VS 248. SKS KRA.

30 VS 634. SKS KRA. 


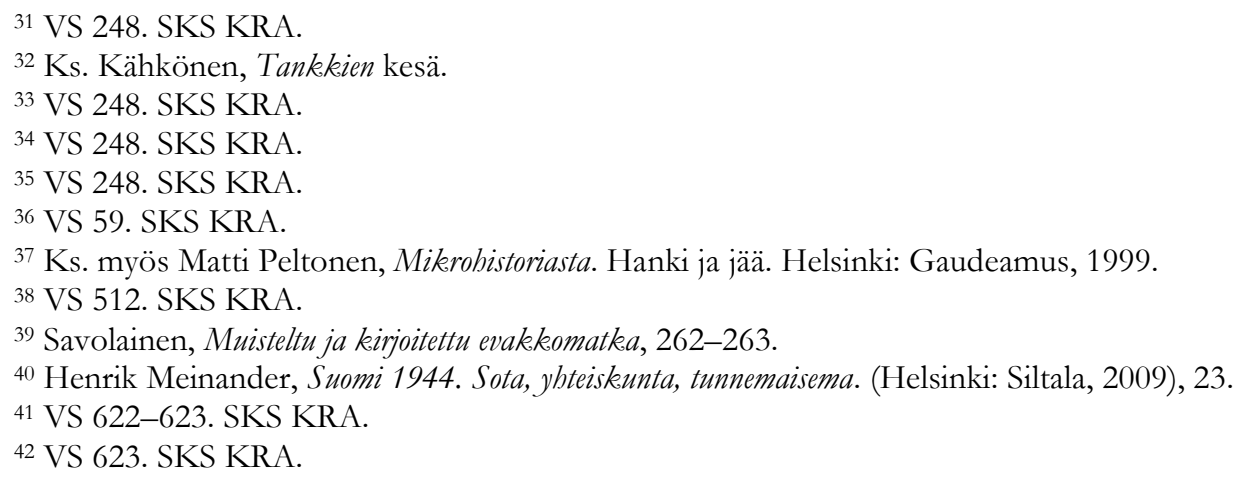

RA.

43 VS 623. SKS KRA.

44 Ville Kivimäki, Kirsi-Maria Hytönen ja Petri Karonen, ”Ennen huomispäivää. Toisen maailmansodan päättyminen Suomessa ja Euroopassa." Teoksessa Raubaton rauha. Suomalaiset ja sodan päättyminen 1944-1950, toim. Ville Kivimäki ja KirsiMaria Hytönen (Tampere: Vastapaino, 2016), 28.

45 Jenni Kirves, "Elämä omiin käsiin. Traumoista selviytymiseen.” Teoksessa Raubaton rauba. Suomalaiset ja sodan päättyminen 1944-1950, toim. Ville Kivimäki ja Kirsi-Maria Hytönen. (Tampere: Vastapaino, 2016), 259-260, $273-281$.

46 VS 624. SKS KRA.

47 VS 624. SKS KRA.

48 VS 383. SKS KRA.

${ }^{49}$ Kivimäki 2016a, 100.

${ }^{50}$ VS 512. SKS KRA.

51 Ville Kivimäki, "Hämärä horisontti, avautuvat tulevaisuudet. Suomalaissotilaat ja syksyn 1944 tunnemaisema." Teoksessa Raubaton rauba. Suomalaiset ja sodan päättyminen 1944-1950, toim. Ville Kivimäki ja Kirsi-Maria Hytönen. (Tampere: Vastapaino, 2016a), 98-99.

52 Jenni Kirves, "Elämä omiin käsiin. Traumoista selviytymiseen.” Teoksessa Raubaton rauba. Suomalaiset ja sodan päättyminen 1944-1950, toim. Ville Kivimäki ja Kirsi-Maria Hytönen. (Tampere: Vastapaino, 2016), 278.

53 VS 357. SKS KRA.

${ }^{54}$ Savolainen, Muisteltu ja kirjoitettu evakkomatka, 367.

55 Seija-Leena Nevala ja Kirsi-Maria Hytönen, ’Toimet, työt ja taakat.” Teoksessa Raubaton rauba. Suomalaiset ja sodan päättyminen 1944-1950, toim. Ville Kivimäki ja Kirsi-Maria Hytönen (Tampere: Vastapaino, 2016), 170.

56 VS 381. SKS KRA.

57 VS 381. SKS KRA.

${ }^{58}$ VS 381. SKS KRA.

${ }^{59}$ VS 622. SKS KRA.

${ }^{60}$ Ville Kivimäki, ”Uusi Suomi. Sotasukupolvi ja sodanjälkeinen aika." Teoksessa Raubaton rauha. Suomalaiset ja sodan päättyminen 1944-1950, toim. Ville Kivimäki ja Kirsi-Maria Hytönen. (Tampere: Vastapaino, 2016b), 301-306.

${ }^{61}$ Ville Kivimäki, "Uusi Suomi. Sotasukupolvi ja sodanjälkeinen aika." Teoksessa Raubaton rauha. Suomalaiset ja sodan päättyminen 1944-1950, toim. Ville Kivimäki ja Kirsi-Maria Hytönen. (Tampere: Vastapaino, $2016 \mathrm{~b}), 301$.

${ }^{62}$ Sarah De Nardi, "An embodied approach to Second World War storytelling mementoes. Probing beyond the archival into the corporeality of memories of the resistance." Journal of Material Culture 19, no. 4 (2014), 447.

${ }^{63}$ Sarah De Nardi, "An embodied approach to Second World War storytelling mementoes. Probing beyond the archival into the corporeality of memories of the resistance." Journal of Material Culture 19, no. 4 (2014): 443-464.

64 Ville Kivimäki, "Uusi Suomi. Sotasukupolvi ja sodanjälkeinen aika." Teoksessa Raubaton rauba. Suomalaiset ja sodan päättyminen 1944-1950, toim. Ville Kivimäki ja Kirsi-Maria Hytönen. (Tampere: Vastapaino, 2016b), 303.

65 VS 247. SKS KRA.

${ }^{66}$ Ruth Finnegan, "Family myths, memories and interviewing." Teoksessa The Oral History Reader, toim. Robert Perks ja Alistair Thomson. (London: Routledge, 2006), 177.

${ }^{67}$ Pirkko Siltala, Taakkasiirtymä. Trauman sïrto yli sukupolvien. Helsinki: Therapeia-säätiö, 2016.

${ }^{68}$ VS 247. SKS KRA.

${ }^{69}$ VS 249. SKS KRA.

70 VS 248-249. SKS KRA.

${ }^{71}$ Ruth Finnegan, "Family myths, memories and interviewing." Teoksessa The Oral History Reader, toim. Robert Perks ja Alistair Thomson. (London: Routledge, 2006), 177.

72 Savolainen, Muisteltu ja kirjoitettu evakekomatka, 260, 367.

${ }^{73}$ Ks. myös esim. Anna-Kaisa Kuusisto-Arponen ja Ulla Savolainen, "The Interplay between Memory and Matter: Narratives of Former Finnish Karelian Child Evacuees.” Oral History 44, no. 2 (2016), 59-68.

${ }^{74}$ Sarah De Nardi, "An embodied approach to Second World War storytelling mementoes. Probing beyond the archival into the corporeality of memories of the resistance." Journal of Material Culture 19, no. 4 (2014), 443-464.

75 Ville Kivimäki, "Uusi Suomi. Sotasukupolvi ja sodanjälkeinen aika." Teoksessa Rauhaton rauha. Suomalaiset ja sodan päättyminen 1944-1950, toim. Ville Kivimäki ja Kirsi-Maria Hytönen. (Tampere: Vastapaino, 2016b), 286-287. 


\section{VS 249. SKS KRA.}

${ }^{77}$ Sarah De Nardi, "An embodied approach to Second World War storytelling mementoes. Probing beyond the archival into the corporeality of memories of the resistance." Journal of Material Culture 19, no. 4 (2014), 443-464.

78 Anna Hynninen, "Arkistokirjoittamisen kontekstualisointi." Teoksessa Tekstien rajoilla. Monitieteisiä näkökulmia kirjoitettuibin aineistoibin, toim. Sami Lakomäki, Pauliina Latvala, ja Kirsi Laurén. (Helsinki: SKS, 2011), 282.

${ }^{79}$ Esim. Kristiina Korjonen-Kuusipuro ja Anna-Kaisa Kuusisto-Arponen "Muistelun monet muodot. Kertomus, kehollisuus ja hiljaisuus paikan tietämisen tapoina.” Elore 24, no. 1 (2017).

${ }^{80}$ Ks. esim. Minna Harjula, "Hyvät, pahat ja kelvolliset. Vammaisuus suomalaisessa yhteiskunnassa 1800-luvun lopulta 1930luvun lopulle." Teoksessa Kuokkavieraiden pidot. Historian marginaalista marginaalihistoriaan, toim. Jarmo Peltola ja Pirjo Markkola. (Tampere: Vastapaino, 1996), 107-121. 